\title{
TEHRIK-I-TALIBAN PAKISTAN: CONSIDERATIONS 3 YEARS AFTER THE SCHOOL ATTACK IN PESHAWAR
}

\section{TEHRIK-I-TALIBAN PAKISTAN: CONSIDERAÇÕES APÓS TRÊS ANOS DO ATAQUE À ESCOLA EM PESHAWAR}

\author{
Rachel Campos ${ }^{1}$ and Priscila Lima Pereira ${ }^{2}$
}

On 16th December 2014, the Army Public School ${ }^{3}$ in Peshawar Pakistan hit by a terror attack. The school, a place of learning, sharing knowledge and experiences between students and teachers, became a battle ground between terrorist and local law enforcement agencies. There was pain and misery all around - children shooting point blank in the school auditorium, blood seeping underneath the carpet, and sounds of panic everywhere. What was just another day in school turned out to be the last one for about 12-16 year-old kids. Hundreds of other children were left with a traumatic experience that will give them nightmares for the rest of their lives. The barbaric attack was conducted by the terrorist group Tehrik-i-Taliban Pakistan.

The attack was planned by Saddam Jan ${ }^{4}$, identified as the mastermind behind the attack. Pakistan is no stranger to terrorist attack, as they have fostered terrorists for years and often uses them as part of their strategic depth policy. These mercenaries also kill to coerce favors from the establishment. But this attack was at the heart of the very establishment that nurtures terrorist groups in Pakistan - The Pakistan Army. Students of the Army Public School come from army families in Pakistan, and this attack was intended to send the army the message that their children are not safe anymore. At 10.30 AM, six men entered the school and started shooting randomly - brutally killing 144 children and teachers.

The survivors recollected that the terrorists went from classroom to classroom killing children and school staff. The attack was planned in such way that the terrorists had no intention of either taking hostage or going out alive of the school. They came on a suicide

\footnotetext{
${ }^{1}$ Independent photographer in humanitarian and extreme situations. Since 2016 researching about Middle East conflicts and the Syrian war. Writing two books about the war in Pakistan in collaboration with Priscila Lima Pereira. ORCID ID: https://orcid.org/0000-0002-9255-6211. Lattes CV: http://lattes.cnpq. br/8058073268225235. Contact: quelzita2008@gmail.com

${ }^{2}$ Law Degree by AEMS, Master's Degree in Int. Relations by the Universidad de Buenos Aires (UBA). Collaborating with the Universidad de Alicante, Spain, FCE-UBA, Argentina and Amity University, India. Articles published in Colombia, Spain, Argentina. The current work is a research in collaboration with Rachel Campos. OCID ID: https://orcid.org/0000-0003-2417-2432. Lattes CV: http://lattes.cnpq. br/5527426533855202 ISA Profile: https://www.isanet.org/My-Profile/UserId/43474. Contact: priscilalimapereira@hotmail.com

${ }^{3}$ APS (Army Public School) is one of the best schools in Pakistan. The school aims boys education exclusively and it follows the army educational system.

${ }^{4}$ Saddam Jan was one of the main leaders of TTP and the commander of one of the most militant Taliban factions operating in Pakistan the Tariq Gedaar group. Jan was identified as the mastermind of the attack to the APS under the order of Umar Mansoor (Tariq Gedaar's main leader) including his participation in many other TTP attacks in Pakistan.
} 
mission whose only purpose was to kill as many as possible before blowing themselves up. Mrs. TahiraQazi, a 63 year woman and principal of the APS, was burnt alive in front of her students in a moment of heinous brutality.

In December 2017, the attack on APS will complete three years and, after all this time, facts are still coming out, such as the black economy that sustains the terrorist groups in Northwestern Pakistan. The Tehrik-i-taliban previously to the attack in the school carried out at least 32 attacks in the country. Although many of its operations were dismantled, its influence and religious ideology among the youth in the tribal areas still persist.

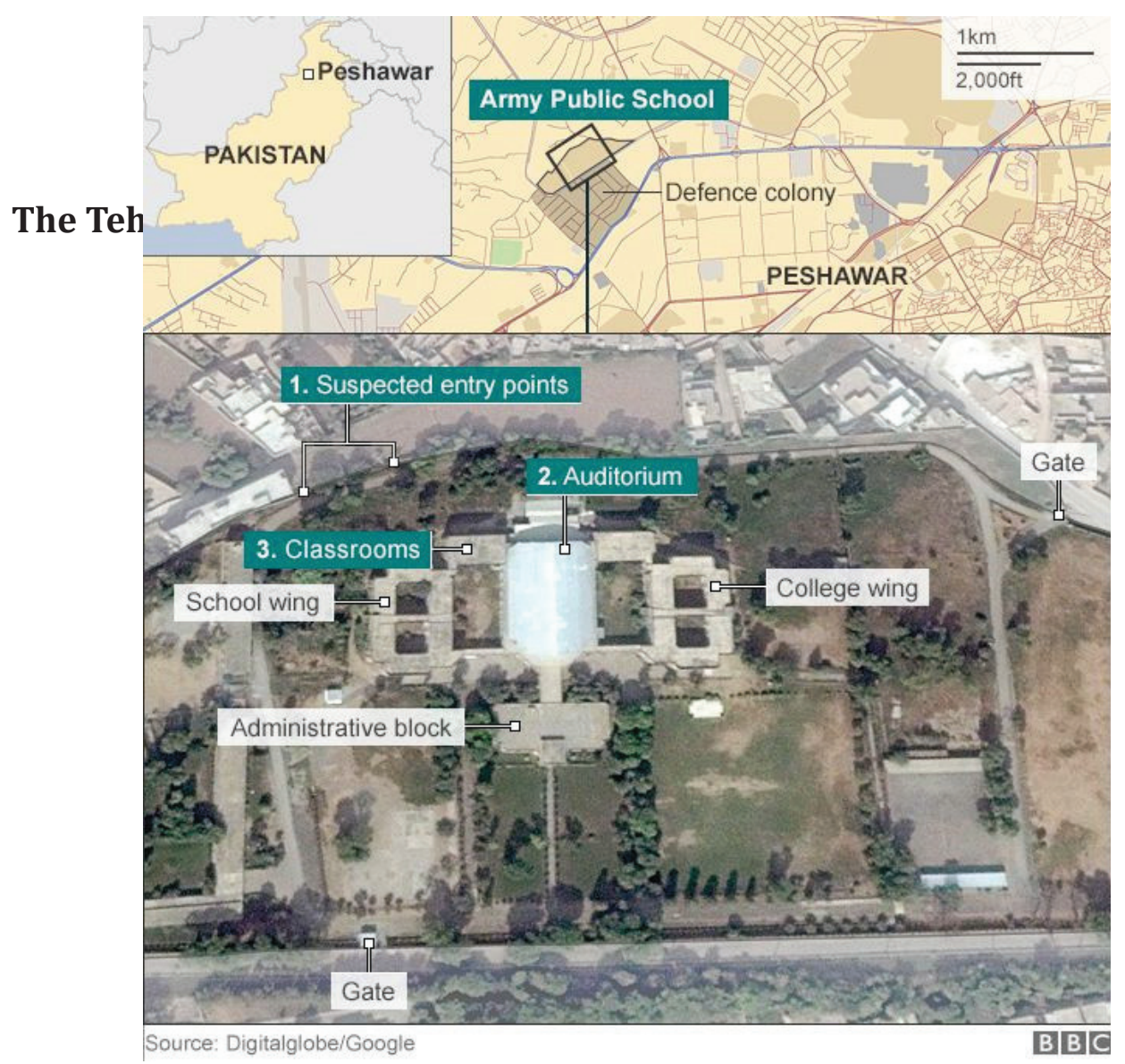

In order to analyze the terrorist attack on the APS, it is necessary to understand the group Tehrik-i-Taliban Pakistan, its motive, ideology and influence in the north of the country.

The Tehrik-i-Taliban Pakistan, or the Taliban Movement of Pakistan in its present form, also known by its acronym TTP, is active in Pakistan since 2007. Some of its operations were reported by US intelligence as early as 2002. TTP was first formed by veterans and ex-Mujahedeen combatants of the Afghanistan war. Some of these Mujahedeen were foreigners who first fought with Americans during Soviet adventures and then fought against the American backed forces post 9/11 US intervention in the region. Some of these combatants held senior positions in the Taliban government in Afghanistan and collaborated with Al-Qaeda. Once Taliban was uprooted, these militants crossed over into Pakistan, which has a porous border with Afghanistan around the Federally Administrated 
Tribal Areas (FATA) region.

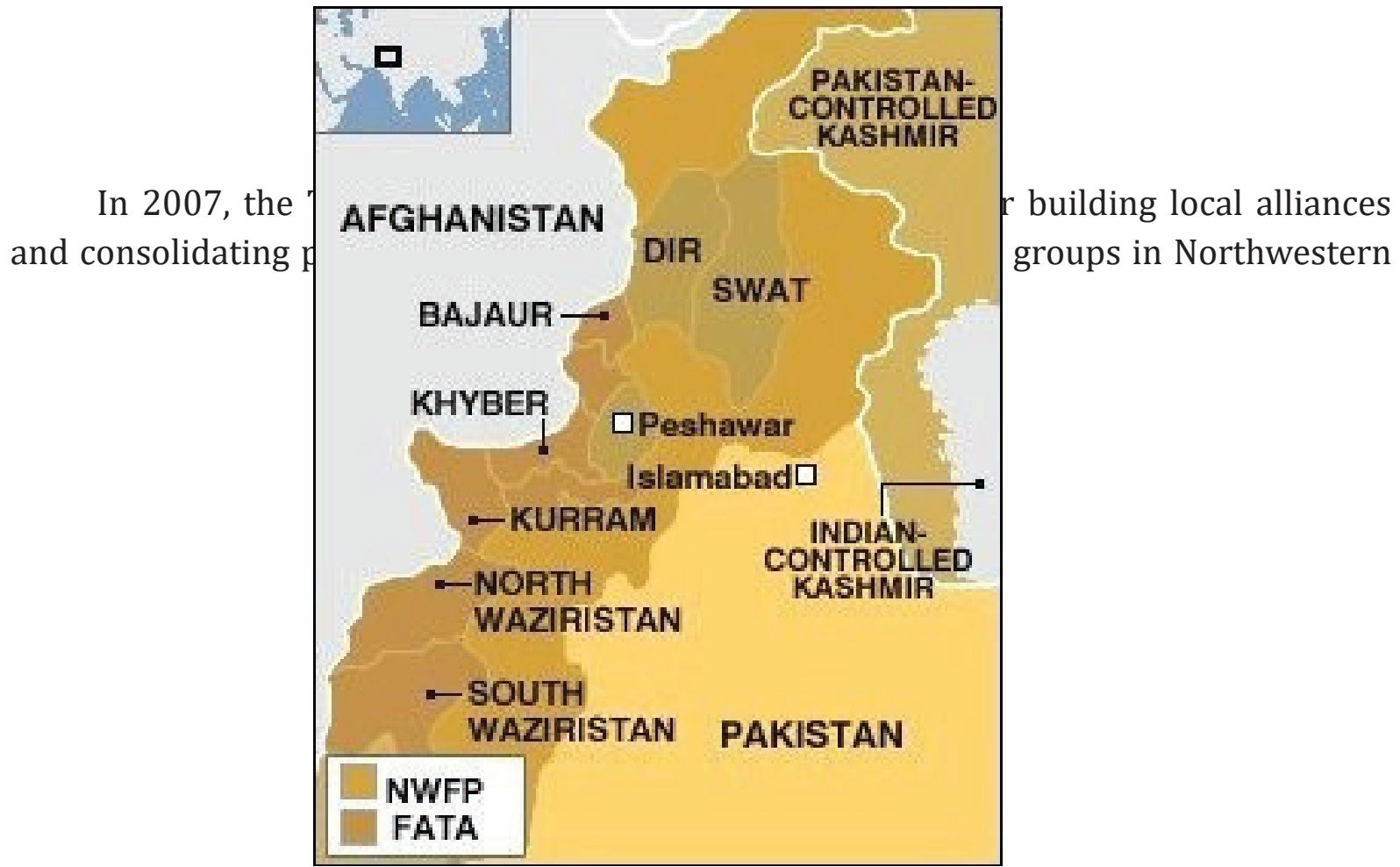

Pakistan. After grouping, TTP was able to centralize its military power and political influence, starting to manage financial operations that would finance their offensive against the Pakistani Government ${ }^{5}$. According to the journalist Syed Irfan Ashraf " understand TTP power we need to understand the role of Jihad, local tribal politics, black money and history of the region".

The TTP was formed in alliance with the local tribal leaders - who not only provided shelter and later protection to them, but also provided operational support. Most of these fleeing militants were foreigners who had little knowledge about the region but had resources to fight in the arid region. The two factors that contributed to the formation and consolidation of the group were tribal dissatisfaction with the government of Pakistan and Pakistan's army operation in the region under the American pressure which led to numerous loss of life on the tribal front. According to the Pakistan government, it is very difficult to monitor the Afghan-Pakistan border since: i) it is not clearly defined and often tribes have members on both sides of the border, and; ii) it has difficult terrain and will require vast amount of resources on the part of the Pakistan government.

The Pakistan government actually does not have direct control over the FATA region and tried to convince the local population - the Waziri - to help the Pakistani Army.

${ }^{5}$ It is important to framework that the main target of the TTP is the Government of Pakistan differently of the Pakistani Taliban that with the support of its ally the Afghan Taliban operates attacking international coalition and the Afghan Security Forces.

${ }^{6}$ ASHRAF, Syed Irfan. TTP turf war, 2014. Available at: https://www.dawn.com/news/451521 . Accessed on: May 20, 2017. 


\section{ensaio}

Negotiations failed, as the government led by the army dictator Pervez Musharaff was not able to convince the tribal leaders to help the military authorities. The operation was considered an attempt to subjugate the tribal region under the direct control of Islamabad and an attempt to take away the autonomous status of the region. The attempts to handover the foreign militants failed completely. ${ }^{7}$

The inability of the Pakistani government to negotiate with the Waziri leaders was one of the main factors that contributed to the rise of TTP. Another critical factor that led to alliance between TTP and Tribal leader was the drone strikes by US Forces in the region. These strikes have tactical node from the Pakistan army and led to numerous deaths of Waziris as collateral damage.

After analyzing all the facts, even if there was no operation and no drone strikes, the TTP or similar force would still have emerged in the region. The military operation and strategic drone strikes just provided a reason to form an alliance.

The critical factor for the emergence of TTP is the power vacuum in the region and the immigration of a militia that can help the local tribal leaders to consolidate their power in exchange of shelter, forwarding its own ideology. The militia was not a threat to local leaders, but could be used by them for their interest in exchange of certain facilities. The biggest failure of the Pakistan government was their inability to make the tribal leaders trust them and devise a trust mechanism where they can meet the demands of the tribal leaders as well as military objectives. TTP alliance with local leaders led to the roots of Taliban in Waziristan and other parts of FATA. This alliance came with a version of Islam which was closer to Taliban and Al-Qaida.

The Taliban version of Islam, an ideology based on establishing a state based on sharia law, organizing the unemployed youths of the region to take up arms. FATA has the highest rate of unemployment in Pakistan. According to numerous sources, the education rate in the FATA region is just $24 \%$ and one of the highest unemployment rate in the world ${ }^{8}$. The TTP ideology joined the fundamentalism of Taliban with the Pashtunwali code widely accepted by the Pashtuns. As to the theological narrative, the young soldiers dying for a divine cause are considered to be martyrs and goes straight to heaven.

Even after assuming power in the Northwestern Region, TTP lacked a central leadership because of the way it was formed: from numerous splinter groups, whose goal is to take on the government of Pakistan. This urge to teach a lesson to the Pakistan military establishment led to the terrorist attack on the Army Public School in 2014.

\section{Why was APS the target?}

The Tehrik-i-Taliban Pakistan claimed responsibility for the attack on the APS. In a statement, Muhammad Umar Khorasani, a TTP's spokesman said that the school was chosen because the government was targeting their families. According to him - "The government is attacking our families and women and we want them to feel our pain in the

${ }^{7}$ ABBAS, Zafar. Pakistan's undeclared war, 2004. Available at: http://news.bbc.co.uk/2/hi/south asia/3645114.stm. Accessed on: May 20, 2017.

${ }^{8}$ ASHRAF, Syed Irfan. TTP turf war, 2014. Available at: https://www.dawn.com/news/451521 . Accessed on: May 20, 2017. 


\section{ensaio}

same way"9.

The school is located in Peshawar, the capital of the province of Kyber Paktunkhwa (KPK). The province of KPK is one of the poorest and most troubled regions in Pakistan. TTP and Taliban ideology are against modern education. In a movement to eradicate modern education from the region, they have destroyed more than 830 schools between 2009 and 2012. Malala Yousuf, the youngest Nobel Peace Prize winner in 2014, was shot dead in this region for the simple crime of being a girl and going to school. The TTP has targeted not only schools, but also modern bazaars and other public places and government facilities. This has led to thousands of deaths because of bomb blasts and terrorist attacks.

What made APS an attractive target was that it is one of the best schools in the region, providing modern education, in addition to most of the school students being children of the military and elite of the region. Attacking the school would send a shockwave in the Pakistan military establishment and undermine its authority in the region.

The school attack in Peshawar was a revenge of the extremist organization against the government of Pakistan. The main target of the TTP was the Government of Pakistan, and most of attacks were aimed at civilians in order to undermine the authority of the government and terrorize the local population. The militants of TTP planned the attack to kill as many children as they could at the APS. The reason for this barbaric attack was to seek revenge for the military operation led by the Pakistan Armed Forces in northwest Pakistan.

\section{Post APS attack: Considerations}

The Pakistan establishment has a shady history of not only fighting terrorist organizations but also nurturing them for their own purposes. Pakistan calls it the "Good Taliban and Bad Taliban". Good Taliban refers to the militia groups that serve its strategic interests, and Bad Taliban the groups like TTP, openly trying to undermine the establishment authority. This dual approach has led to numerous casualties and terrorist attacks on Pakistani soil.

Pakistan is systematically fighting the terror of radical groups operating in tribal areas that they consider a threat to their existence, but still supply resources to organizations that support it. In this conflict, civilians are the main victims, and the role of oppressor and oppressed is not always clearly defined. Both the government and the militants can play the same role of oppressing the people and often at the same time. When the government launches drone attacks civilians are killed as collateral damage. The TTP targets not only government officials, but also civilians doing their normal day chores.

In the past, Pakistan has failed to acquire the support of tribes in the northwest of the country. Only after prolonged negotiations with tribal leaders and mindless killings by TTP did tribal leaders allow the military to enter the region. The Pakistan government needs to build a better relationship with the tribes to exhaust the room for groups like TTP. In order to build this trust, they need to start sharing greater economic resources,

\footnotetext{
${ }^{9}$ Massacre de inocentes no Paquistão mostra como não há limites para a barbárie, 2015. Available at: http:// www.comunicacaoecrise.com/site/index.php/artigos/738-massacre-de-inocentes-no-paquistao-mostracomo-nao-ha-mais-limites-para-a-barbarie . Accessed on: Jun 23, 2017.
} 


\section{ensaio}

respect local autonomy, and provide economic opportunities for the youth of the region.

The brutality of APS alerted both the government and the military establishment of how fragile the region is. In order to bring peace in the region, the government has to build institutions that can provide a political alternative to militia-based justice. They must bring the tribal leaders on the table and build trust through power sharing and empowering the tribes to create opportunities for their youths.

\section{References:}

ABBAS, Hassan. A Profile of Tehrik-I-Taliban Pakistan CTC Sentinel. West Point, NY: Combating Terrorism Center. Available at: https://ctc.usma.edu/posts/a-profile-oftehrik-i-taliban-pakistan. Accessed on: June 23, 2017.

ABBAS, Zafar. Pakistan's undeclared war, 2004. Available at: http://news.bbc.co.uk/2/hi/ south_asia/3645114.stm. Accessed on: May 20, 2017.

ASHRAF, S. I. Militancy \& black economy. Mar 22, 2009. Available at: https://www.dawn. com/news/451521. Accessed on: May 29, 2017.

BAJORIA, Jayshree. Pakistan's New Generation of Terrorists. Council on Foreign Relations, 6 February 2008. Available at: https://www.cfr.org/backgrounder/pakistans-newgeneration-terrorists Accessed on: June 27, 2017.

CHAPMAN, B. My brother in the fight for education :MalalaYousafzai meets survivor of Peshawar school massacre. March 12, 2015. Avaliable at: http://www.itv.com/news/201503-12/malala-yousafzai-meets-survivor-of-peshawar-school-massacre/. Accessed on: May 29, 2017.

GALL, Carlotta. KHAN, Ismail.SHAH, Pir Zubair.\& SHAH, Taimoor. Pakistani and Afghan Taliban Unify in Face of U.S. Influx. New York Times. March 2009. Availble at: http://www. nytimes.com/2009/03/27/world/asia/27taliban.html. Accessed on: June 23, 2017.

141 people, mostly students killed by Taliban in Pakistan army school seizure. Dec 16, 2014. Available at: https://www.rt.com/news/214707-pakistan-school-hostagetaliban/. Accessed on: May 29, 2017.

MARKEY, Daniel. A false choice in Pakistan. Foreign Affairs, july/august 2007. Available at: https://www.foreignaffairs.com/articles/asia/2007-07-01/false-choice-pakistan . Accessed on: May 22, 2017.

Peshawar school massacre: What we know. Dec 17, 2014. Available at: http://www.bbc. com/news/world-asia-30488503. Accessed on: May 29, 2017.

RASHID, Ahmed. Taliban: Militant islam, oil and fundamentalism in Central Asia. New York, Yale University Press, 2000.

Remembering lives lost in the Peshawar school attack, 2016. Available at: https://www. dawn.com/news/1223313/remembering-lives-lost-in-the-peshawar-school-attack 


\section{ensaio}

Accessed on: May 18, 2017.

RETTER, E. Pakistan school massacre: Taliban killed his brother and burned teacher alive but won't defeat our son. 1 March 2015 Avaliable at: http://www.mirror.co.uk/news/ uk-news/pakistan-school-massacre-taliban-killed-5255771. Accessed on: May 29, 2017.

YUSUFZAI, Ashfaq. Mastermind of Peshawar school attack killed, 26 dec. 2016. Available at: http://www.telegraph.co.uk/news/worldnews/asia/pakistan/11313678/Mastermindof-Peshawar-school-attack-killed.html. Accessed on: June 27, 2017.

Texto recebido em: 30 de Junho de 2017

Aprovado para publicação em: 12 de Fevereiro de 2018 